\title{
Evaluation of Tax Evasion Models Based on the Views from Neoclassical to Behavioral Economics: Analytical Hierarchy Process Approach in Economy of Iran
}

\author{
Vahideh Ahmadi ${ }^{1}$ \\ Rooholah Shahnazi ${ }^{2}$ \\ Karim Eslamloueyan ${ }^{3}$ \\ Ahmad Sadraei Javaheri ${ }^{4}$ \\ s.ahmadi@rose.shirazu.ac.ir \\ rshahnazi2004@yahoo.com \\ keslamlo@shirazu.ac.ir
}

Received: 14/03/2021 | Accepted: 31/05/2021

\begin{abstract}
Taxes, as the most important source of government revenue and one of the economic policy instruments, play a key role in development policies. In this study, the evolution process of different models of tax evasion (from neoclassical approach to behavioral economics) is investigated, also the assumptions and variables of these models are analyzed. Then, using the analytical hierarchy process (AHP) based on the opinions of tax experts, the factors affecting tax evasion are ranked in different models to determine which model is superior in explaining and measuring the factors affecting tax evasion in Iran. The results show that instability of preferences, loss avoidance, and ambiguity avoidance are the main factors influencing tax evasion. Correspondingly, rational behavior and behavioral adaptation have the least explanatory power as regards tax evasion in Iran. Based on the results, in analyzing and measuring Iran's tax evasion, a paradigm shift towards behavioral economy models is needed.
\end{abstract}

Keywords: Tax Evasion, Neoclassical Economics, Behavioral Economics, Analytical Hierarchy Process (AHP), Tax Policy.

JEL Classification: H26، C60.

1. Ph.D. Student of Economics, Faculty of Economics, Management and Social Sciences, University of Shiraz, Shiraz, Iran.

2. Associate Professor, Department of Economics, Faculty of Economics, Management and Social Sciences, University of Shiraz, Shiraz, Iran (Corresponding Author).

3. Professor, Faculty of Economics, Department of Economics, Management and Social Sciences, University of Shiraz, Shiraz, Iran.

4. Associate Professor, Department of Economics, Faculty of Economics, Management and Social Sciences, University of Shiraz, Shiraz, Iran. 


\section{ارزيابى مدلهاى سنجش فرار مالياتى از اقتصاد

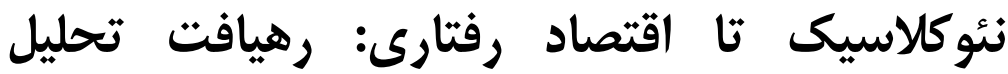 سلسلهمراتبى در اقتصاد ايران \\ s.ahmadi@rose.shirazu.ac.ir | \\ وحيده احمدى دئس}

دانشجوى دكترى اقتصاد، دانشكده اقتصاد، مديريت و علوم اجتماعى، دانشگاه شيراز، شيراز، ايران. rshahnazi2004@yahoo.com

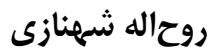

دانشيار، گروه اقتصاد، دانشكده اقتصاد، مديريت و علوم اجتماعى، دانشكاه شيراز، شيراز، ايران

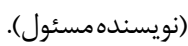

keslamlo@shirazu.ac.ir

كريه اسلاملوييان

استاد، گروه اقتصاد، دانشكده اقتصاد، مديريت و علوم اجتماعى، دانشعاه شيراز، شيراز، ايران.

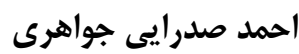

دانشيار، تروه اقتصاد، دانشكده اقتصاد، مديريت و علوم اجتماعى، دانشعاه شيراز، شيراز، ايران.

\section{مقاله بروهشى}

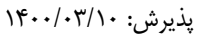

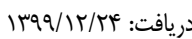

جكيده: ماليات به عنوان مهرمترين منبع درآمدى دولتها و يكى از ابزارهاى سياستى در

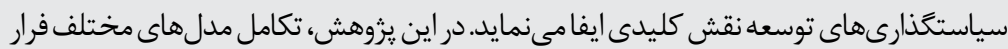

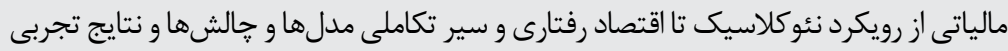

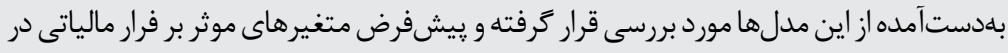

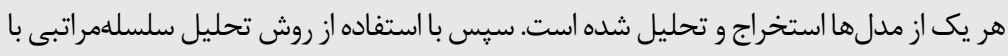

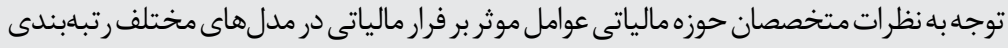

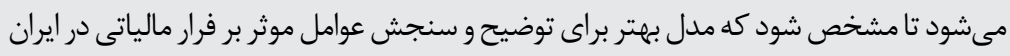

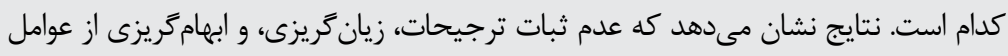

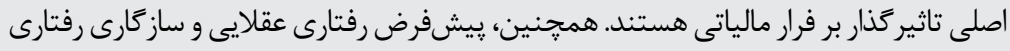

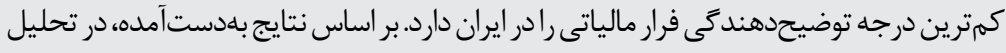

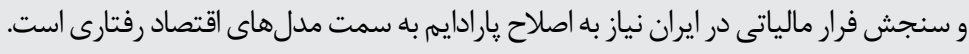

كليدوازهها: فرار مالياتى، اقتصاد نئوكلاسيك، اقتصاد رفتارى، تحليل سلسلهمراتبى، سياست گذارى مالياتى. طبقدبندى C60, H26: JEL. 


\section{مقدمه}

انجام تعهدات دولت در عرصههاى اقتصادى و اجتماعى و تلاش در راستاى تحقق اهدافى همجون رشد اقتصادى، ثبات قيمتها، افزايش اشتغال، و توزيع عادلانه درآمد نيازمند منابع در آمدى است. تجربه كريه كشورها نشان مى دهد كه در آمدهاى مالياتى مناسبترين منبع در آمدى دولتهاست و ماليات به عنوان ابزارى كارامد دردي در راستاى اجراى سياستهاى اقتصادى و هدايت اقتصاد در مسير اهداف كلان اقتصادى نظير تثبيت اقتصادى، ايجاد اشتغال، رشد اقتصادى، و بهبود رفاه اجتماعى محسوب مى رَردد (Hadian \& Tahvili, 2013). يكى از

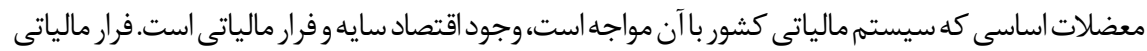
نهتنها به كاهش در آمد منجر مى

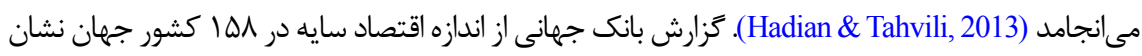

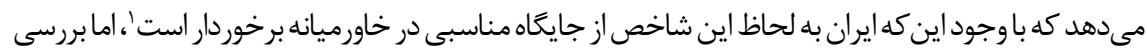

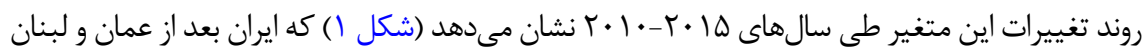
بيشترين درصد رشد رادر اندازه اقتصاد سايه در اين دوره زمانى دارد (Medina \& Schneider, 2018). افزايش

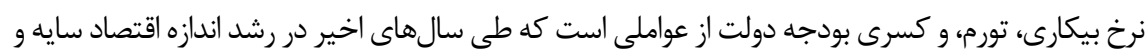
فرار مالياتى در كشور تاثير گذار بوده است (Motallebi et al., 2020).

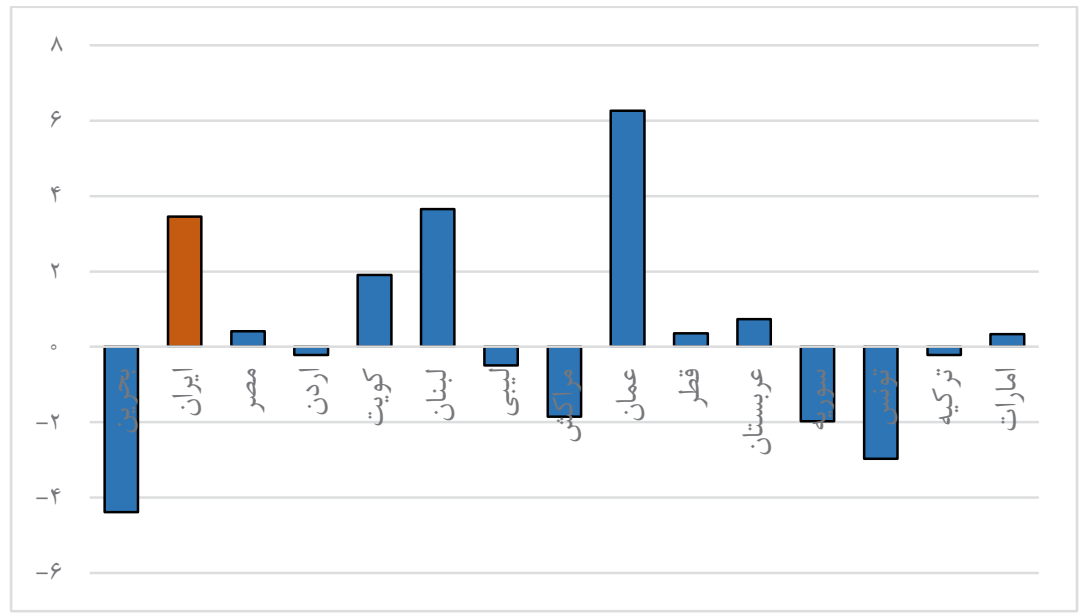

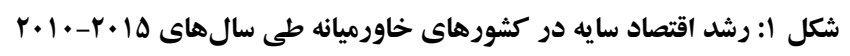

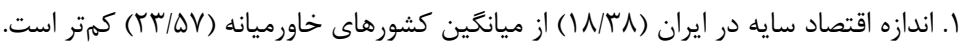


Sadeghi \& Shakibaei, 2001) تاكنون ارزيابى هاى آمارى متعددى توسط تحليلكَران مالى و اقتصاددانان و اميدى يور و همكاران، (qج (1) در تخمين فرار مالياتى و اقتصاد سايه در اقتصاد ايران انجام گرفته

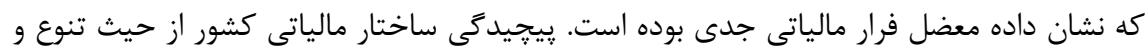
عدم شفافيت قوانين و مقررات در ريوند با ساختار اقتصادى خاص كشور به افزايش احتمال و تنوع مانى روشهاى فرار مالياتى در اقتصاد منجر شده است. در عين حال، ضعف نهادى و سازوكارهاى متنوع جمع آورى ماليات مشكلات را تشديد نموده است. با توجه به اهميت فرار مالياتى در كاهش معنادار در آمدهاى مالياتى در بيشتر كشورهاى جهان،

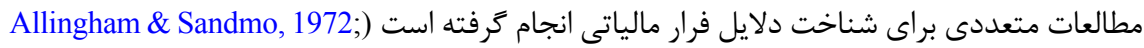
Friedland, 1982; Snow \& Warren, 2007 تا اقتصاد رفتارى را شامل مى گردد، يارامترهاى متعددى را در آزمون عوامل موثر بر فرار مالياتى مورد

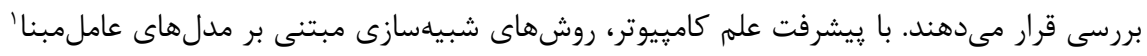

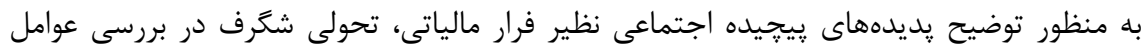

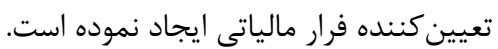

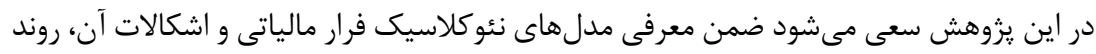
تكاملى اين مدلها از اقتصاد نئوكلاسيك به اقتصاد رفتارى به منظور تبيين دقيق نتايج آنها مان بانتايج

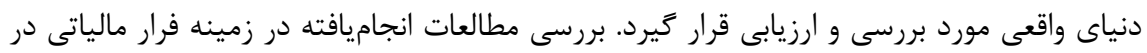

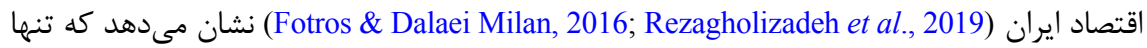
بر عوامل اقتصادى موثر بر اين يديده تاكيد گرديده و نقش عوامل روانى و رفتارى، و تاثير هنجارهاى

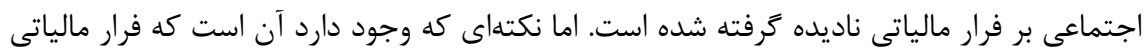

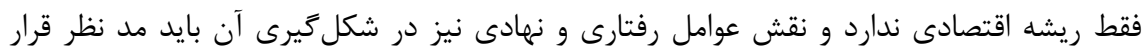
كيرد (Andrei et al., 2014; Hokamp, 2014; Korobow et al., 2007). با توجه به ابهامات موجود در خصوص تعيين كاراترين يارامترها براى تحليل فرار مالياتى در اقتصاد ايران، پِ از بررسى نظريههاى موجود و استخراج فروض و يارامترهاى مرتبط با هر مدل، معيارهاى اصلى اين مدلها استخراج شدند و از

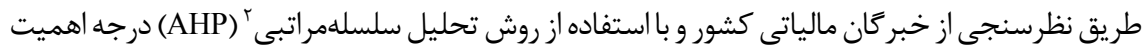
معيارها به منظور تعيين مناسبترين يارامترها براى تحليل فضاى ماليات در اقتصاد كشور تعيين گرديد. 
يزوهش شامل جهار بخش است. يُ از بيان مقدمهاى در خصوص اهميت در آمدهاى مالياتى در

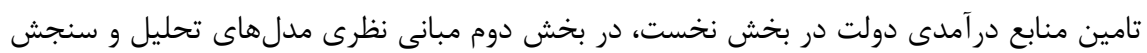

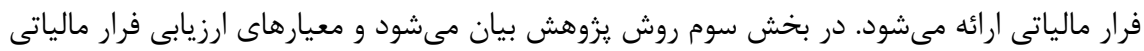

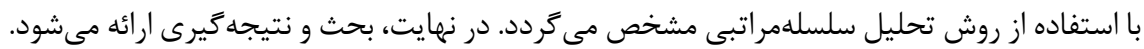

\section{مبانى نظرى : مثوهش}

طبيعت جرمشناسانه فرار مالياتى و مجازات ناشى از آن سبب مىشود كه فرار مالياتى عموماً بهآسانى قابل مشاهده نباشد و اقتصاددانان از روشهاى غيرمستقيهم براى شناسايى و سنجش فرار مالياتى استفاده كنند. همانطور كه در شكل (Y) مشخص شده، مدلهاى ارزيابى و تحليل فرار مالياتى شامل سه دسته اصلى مدلهاى استاندارد با مطلوبيت انتظارى، مدلهاى غيرانتظارى تحت ريسك يا ناطمينانى، و

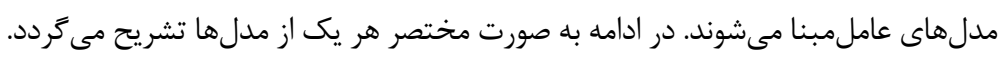
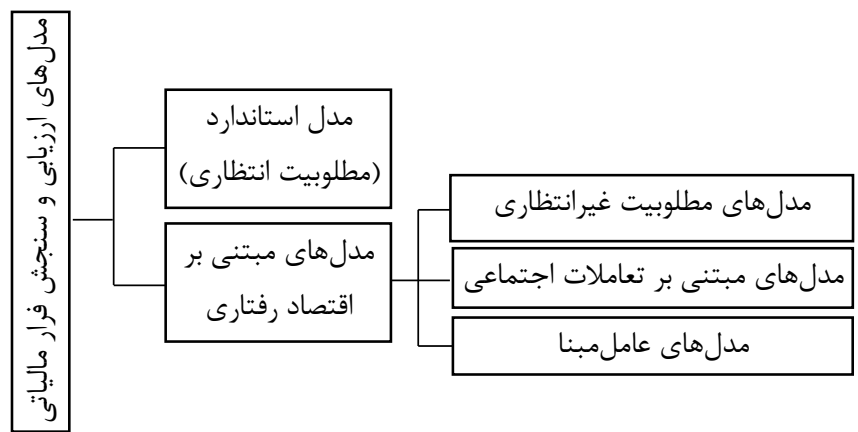

شكل ז: مدلهاى ارزيابى و تحليل فرار مالياتى

\section{مرورى بر مدلهاى تصميم براى فرار مالياتى}

در اين بخش به صورت خلاصه مرورى بر نظريههاى اقتصادى كه در تصميم براى فرار مالياتى كاربرد دارد ارائه مى گردد. به اين منظور ابتدا مدل مطلوبيت انتظارى توصيف مى شود و محدوديتهاى

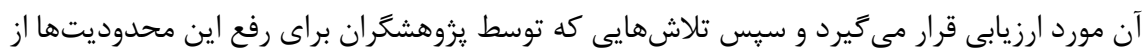


طريق وارد كردن ايدههاى اقتصاد رفتارى به مدلها به انجام رسيده، به صورت مختصر ارائه مى

\section{مدلهاى مبتنى بر مطلوبيت انتظارى}

نقطه شروع مدلسازى تصميم براى فرار مالياتى، بررسى رفتار يرداختكننده ماليات با سطح

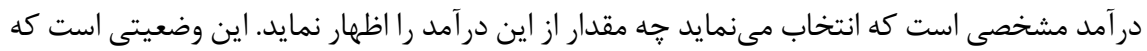
براى اولين بار در يزوهش آلينكام و ساندمو (9VT ( ) مورد مطالعه قرار گرفت. فرض مىشود كه در آمد افراد براى سازمان مالياتى ناشناخته است. همجنين، يرداخت كننده احتمال هدف مميزى را ميى دراند.

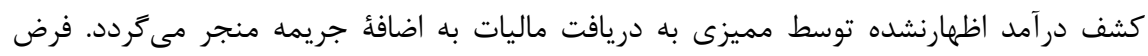

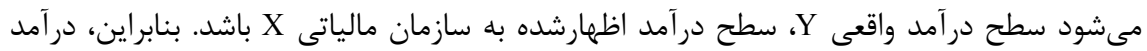
اظهارنشده معادل E= Y-X خواهد بود. نرخ ماليات در T ثابت است و جريمه اخر مميزى صورت گيرد، معادل f E خواهد بود. مسئله تصميم براى يرداخت كننده انتخاب سطح E خواهد بود. بعد از تصميم

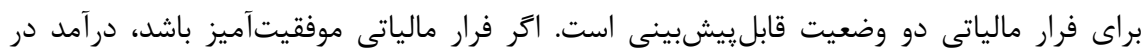
$Y^{c}=Y-\tau Y-f \tau E$ دسترس فرد $Y^{n}=Y-\tau X$ و اگر فرار شناسايى شود، درآمد در دسترئ خواهد بود. اين دو وضعيت با احتمال هدف 1-p و p اتفاق مىافتد. يرداخت كننده سطح در آمد هدف

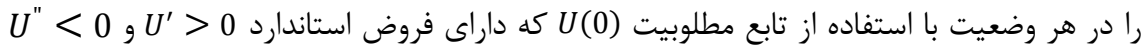

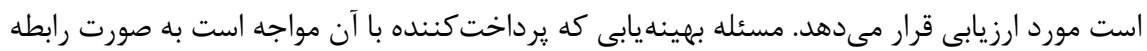

$\max V=P U(Y[1-\tau]-f \tau E)+[1-P] U(Y[1-\tau]+\tau E)$

شرايط مرتبه اول و دوم براى دستيابى به نقطه بهينه داخلى' به صورت روابط (Y) و (T) بهدست

$-P f U^{\prime}\left(Y^{c}\right)+[1-P] U^{\prime}\left(Y^{n}\right)=0$

$S \equiv P f^{2} U^{\prime \prime}\left(Y^{c}\right)+[1-P] U^{\prime \prime}\left(Y^{n}\right)<0$

شرط كافى فرار مالياتى از طريق معادله (r) در E = بهدست مى آيد. اين نشان مى دهد كه سطح انتخاب براى فرار مالياتى $0>0$ زمانى بهينه است كه شرط (P)

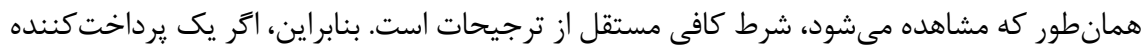

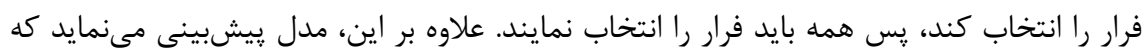


همه يرداخت كنند

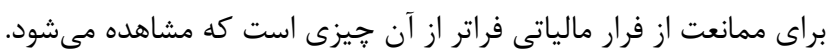

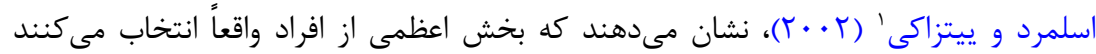
كه همه درآمد خود را اظهار نمايند و به اين صورت اولين جالش مدل نئوكلاسيك فرار مالياتى

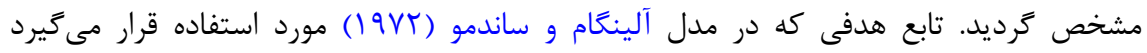

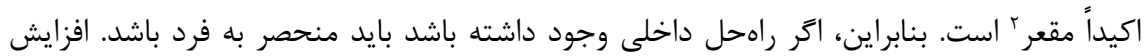

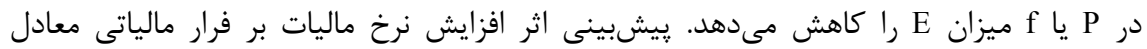

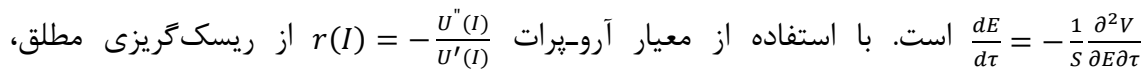

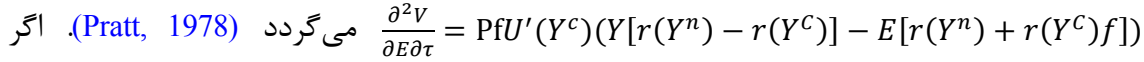
ريسك گريزى مطلق كاهشى باشد، زمانى كه درآمد افزايش مى يابد $r\left(Y^{n}\right)<r\left(Y^{c}\right)$ است. بنابراين، > ن 0

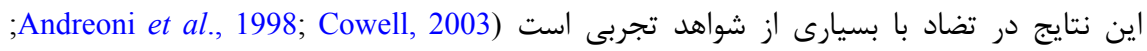

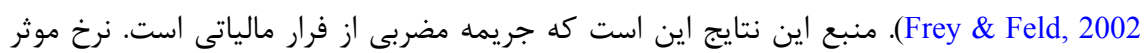
جريمه معادل fqE است. بنابراين، جريمه زمانى كه نرخ ماليات كاهش ميى يابد سختتر مىشود

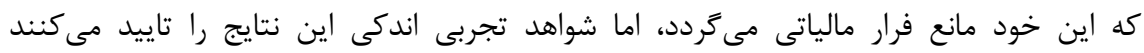

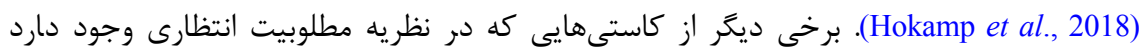

$$
\text { عبارتاند از: }
$$

ا. تابع مطلوبيت لزوماً خطى نيست و با توجه به متفاوت بودن ترجيحات افراد در بيشتر موارد به صورت غيرخطى خواهد بود. ז. افراد به احتمالات زياد و كم نسبت به احتمالات متوسط حساسيت بيشترى نشان ميى دهند. بنابر اين، احتمالات يكسان ارزش مساوى ندارند و ارزش واقعى احتمالات با ارزش عددى آنها متفاوت

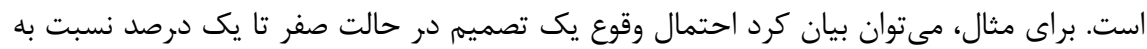

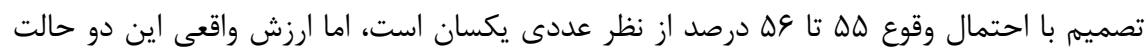
براى فرد تصميمگيرنده يكسان نيست. r. ترجيحات افراد در طول زمان تغيير مى كند. بنابراين، مطلوبيت آنها نيز برحسب دورههاى 
زمانى متفاوت خواهد بود. اما در نظريه مطلوبيت انتظارى فرض مىشود كه ميزان مطلوبيت همواره

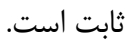

f. حساسيت افراد نسبت به تابع زيان در مقايسه با تابع سود بيشتر است. بنابراين، افراد نسبت

به كمينه كردن زيان خود اقدام مى كنند (Cartwright, 2018).

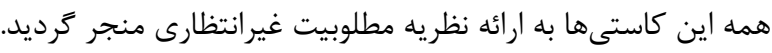

\section{مدلهاى مبتنى بر مطلوبيت غيرانتظارى'}

در نظريه مطلوبيت غيرانتظارى مدلهاى انتخاب تحت ريسك و ناطمينانى' مطرح است كه به صورت مختصر مدلهاى انتخاب تحت ريسك و نالطمينانى مورد بررسى قرار مى كيرد.

\section{مدلهاى انتخاب تحت شرايط ريسك}

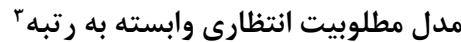

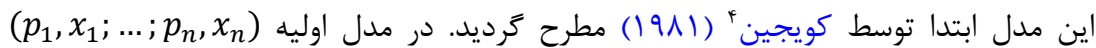

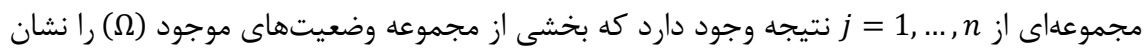
مى دهد. احتمالات مجاى

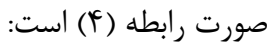

$\sum_{j=1}^{n} \pi_{j} U\left(x_{j}\right)$

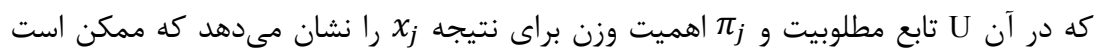

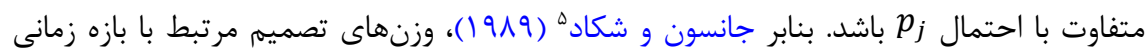

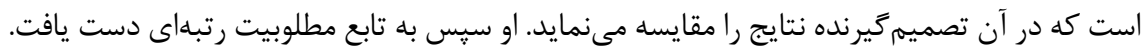

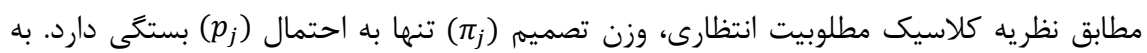

1. Non-Expected Utility Theory

ז. تفاوت بين ريسك و نااطمينانى در اين است كه در ريسك احتمال وقوع هر پيامد مشخص است، اما در

3. Rank Dependent Expected Utility Theory

ناطمينانى مشخص نيست.

5. Johanson \& Schekade 
عبارت ديكر، وزن تصميمم مستقل از ساير نتايج و احتمالات ممكن است. پس تابع مطلوبيت انتظارى به صورت رابطه (ه) بيان مىشود:

$\sum_{j=1}^{n} w\left(p_{j}\right) U\left(x_{j}\right)$

نكتهاى كه وجود دارد آن است كه تصميمگيرى فرد نهتنها به نتيجهاى كه بهدست مى آورد وابسته است، بلكه به احتمال آن نتيجه و مقايسه آن با ديكر نتايج نيز بستكى دارد. فرض كنيد $\left(\frac{1}{3}, 30 ; \frac{1}{3}, 20 ; \frac{1}{3}, 10\right)$

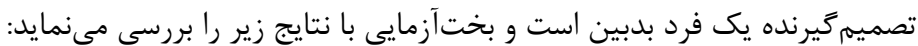

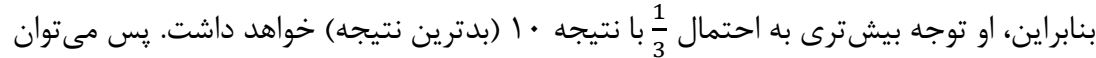
بيان داشت كه وزن تصميم براى نتيجه (10 كمترى به ساير نتايج دارد ( بان خواهد داشت. يس هم قانت $\pi_{1}=\frac{1}{6}$ قانون مورفى'، بدبينى، ناشى از باور غيرمنطقى از وقوع يك حادثه نامطلوب است كه منجر مىشود تصميمَّيرنده احتمالات غيرواقعى و نامطلوب را بيش از حد وزندئى ندى نمايد كه اين امر او را وادار به كرفتن تصميمهاى احتياطى و حسابشده مىنمايد.

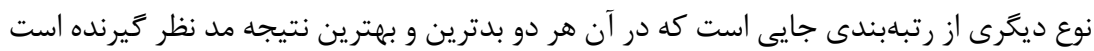

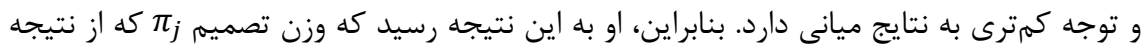

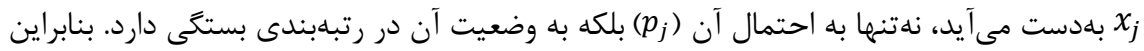
اگر $R D U\left(p_{1}, x_{1} ; \ldots p_{n}, x_{n}\right)=\sum_{j=1}^{n} \pi_{j} U\left(x_{j}\right)$

كه در آن

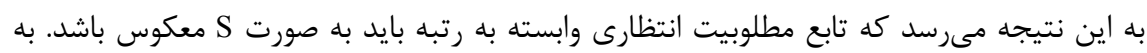

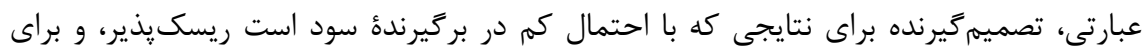

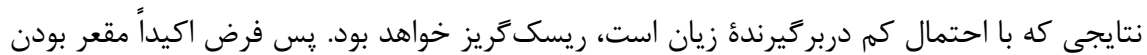

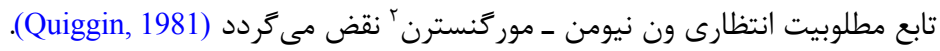




\section{مدل جشمانداز'}

ايده اصلى نظريه جشهمانداز اين است كه نقطه مرجعى گ وجود دارد كه نسبت به آن زيانها و فوايد

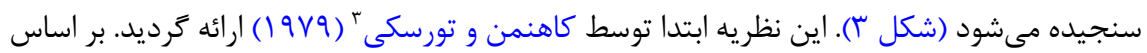

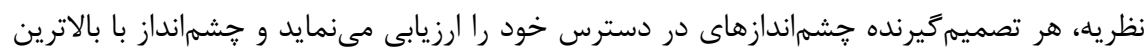
ارزش را انتخاب مى كند (Kahneman Tversky, 1979). اين فرايند با بررسى تصميم كيرندهاى كه انتخاب بين دو جشمانداز را مورد بررسى قرار مى دهد به شرح زير تشريح مى مَردد:

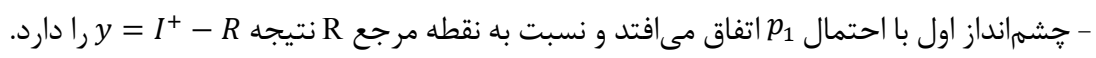
- جشم|نداز ديخر با احتمال 20 نسبت به نقطه مرجع نتيجه R اين تابع جشمانداز به صورت رابطه (V) اندازهخيرى مىشود:

$v=w_{1}\left(p_{1}\right) v(x)+w_{2}\left(p_{2}\right) v(y)$

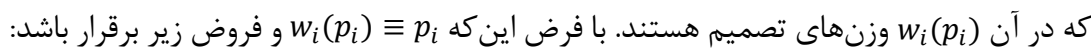

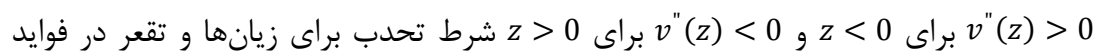

برقرار خواهد بود (Hashimzade et al., 2013). براى

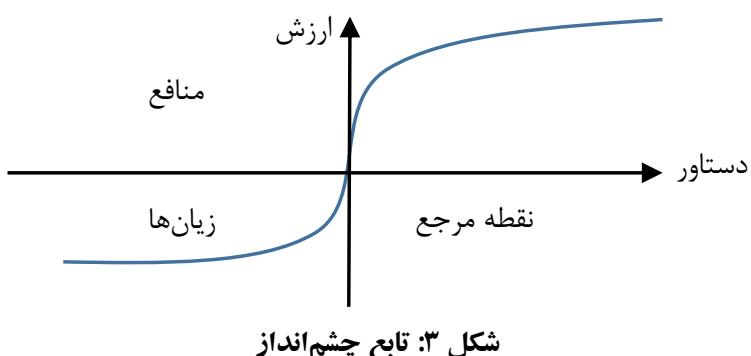

1. Prospect Theory 


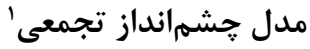

نظريه جشمهانداز انتخاب ميان جشم|ندازهاى ريسكى را براى تعداد كمى از نتايج نشان مىدهد كه با

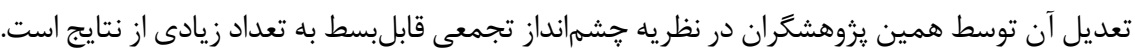

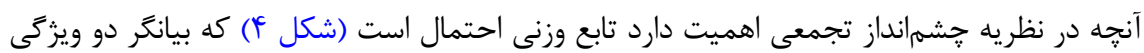
كاهش حساسيت و جذابيت است. تغيير احتمال تصميمگيرى فرد بين صفر و يك ناشى از ويزگى كاهش حساسيت، تعيين كننده تحدب يا تقعر تابع (شكل تابع) است. به دليل وجود نقطه مرجع، افراد احتمال

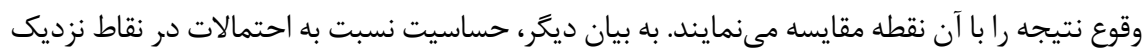

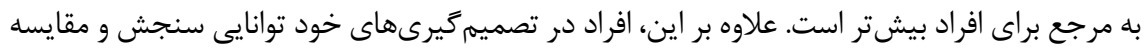

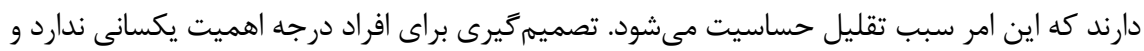
درجه اهميت آنها توسط ويزگى جذابيت تعيين مى آشود. بر مبناى اصل جذابيت، تابع وزنى احتمال در

بالا يا پايين خط لهأ درجه قرار مى گيرد (Mosleh et al., 2013).

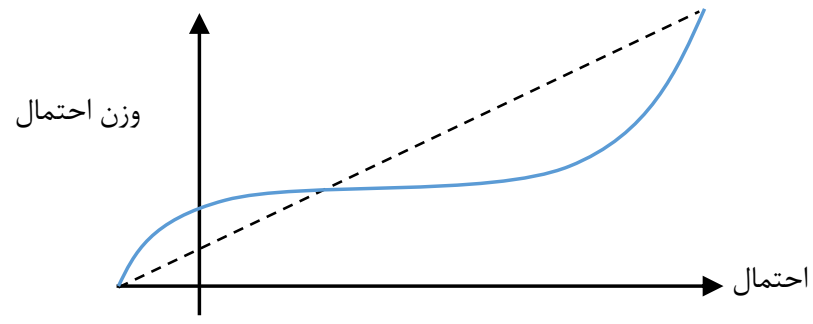

بنابراين، جشمانداز شامل مجموعه زوجهاى

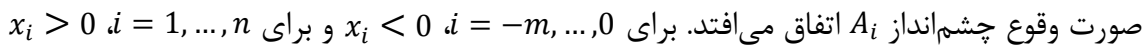
است. +f و f $f^{-}$به عنوان بخشهاى مثبت و منفى تابع جشمانداز معرفى مىشوند. بنابراين، نظريه

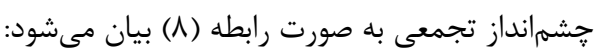

$\left(v(f)=v\left(f^{+}\right)+v\left(f^{-}\right)\right.$

كه در آن صورت رابطه (9) هستند: 


$$
\left\{\begin{array}{c}
w_{n}^{+}=w^{+}\left(A_{n}\right), w_{-m}^{-}=w^{-}\left(A_{-m}\right) \\
w_{i}^{+}=w^{+}\left(A_{i} \cup \ldots \cup A_{n}\right)-w^{+}\left(A_{i+1} \cup \ldots \cup A_{n}\right) \\
w_{i}^{-}=w^{-}\left(A_{-m} \cup \ldots \cup A_{i}\right)-w^{-}\left(A_{-m} \cup \ldots \cup A_{i-1}\right)
\end{array}\right\}
$$

اگر احتمال مثبت

$$
\left\{\begin{array}{c}
w_{n}^{+}=w^{+}\left(p_{n}\right), w_{-m}^{-}=w^{-}\left(p_{-m}\right) \\
w_{i}^{+}=w^{+}\left(p_{i}+\cdots+p_{n}\right)-w^{+}\left(p_{i+1}+\cdots+p_{n}\right) \\
w_{i}^{-}=w^{-}\left(p_{-m}+\cdots+p_{i}\right)-w^{-}\left(p_{-m}+\cdots+p_{i-1}\right)
\end{array}\right\}
$$

از آنجايى كه شكل تابعى مشخصى براى پيامدها تعريف نشده است، اما به نظر مىرسد نظريه

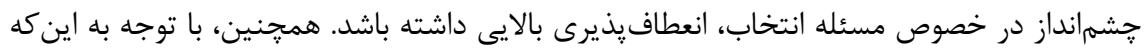
اين تابع در فوايد مقعر و در زيانها محدب است، شواهد روانشناسى را هم در بر خواهد كرفت. با بان

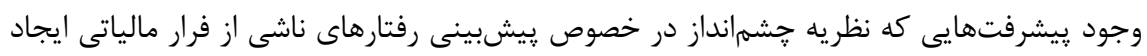
نموده است، اما هنوز تناقضاتى در ييشبينى اين مدلها (بلويثه تاثير نرخ ماليات بر فرار مالياتى) مشاهده مى

\section{مدلهاى انتخاب تحت شرايط ناطمينانى}

\section{مدلهاى مبتنى بر ابهامكريزى' - مائ}

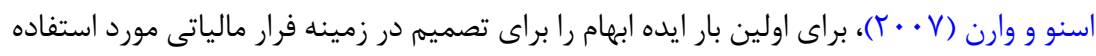
قرار مى دهند. ابهام در مدل آنان به معناى كمبود اطلاعات دقيق در خصوص احتمال مميزى است. بنابراين، از توزيع احتمال مرتبه دوم براى احتمال مميزى استفاده مى كنند. افزايش در ابهام به

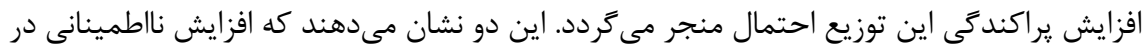

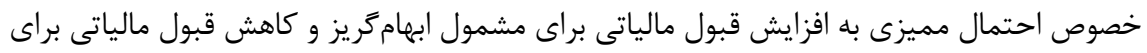

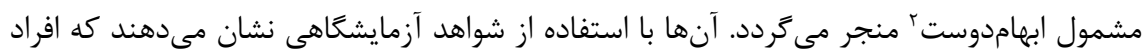
بر اساس ترجيحات در ابهام، ناهمگن هستند. يس ترجيحات افراد براى فرار مالياتى بسته به ابهام در

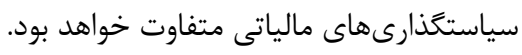


ايده بالاتر يا پايينتر بودن ابهام، ايدهاى جالب توجه در تصميم براى قبول مالياتى است، زيرا

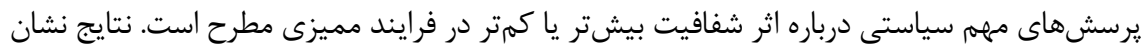

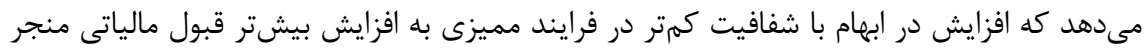

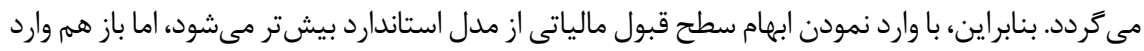

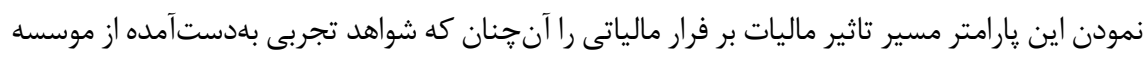

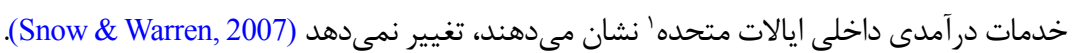

\section{مدلهاى مبتنى بر هزينهاى فيزيكى و هنجارهاى اجتماعى'}

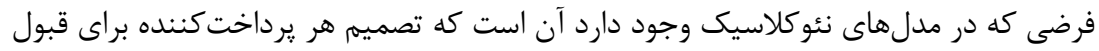

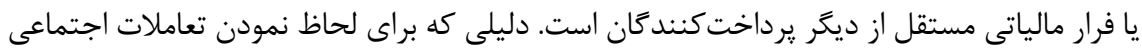

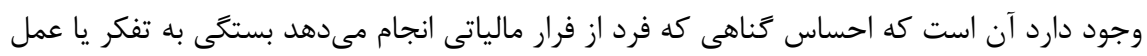

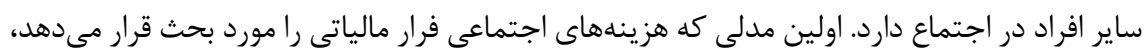

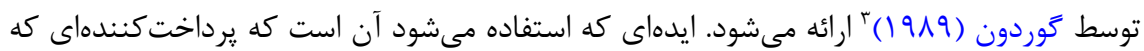

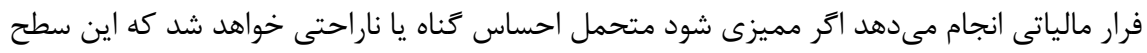

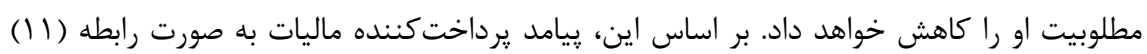

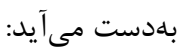
$V=P U(Y[1-\tau]-f \tau E)+[1-P] U(Y[1-\tau]+\tau E)-\chi E$

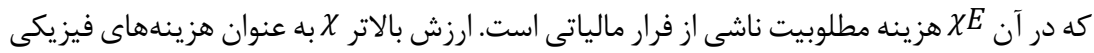

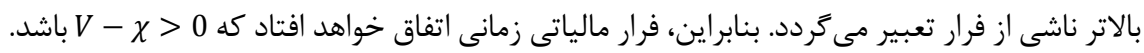

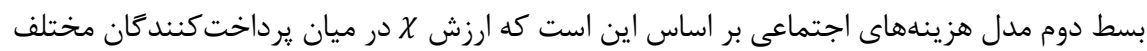

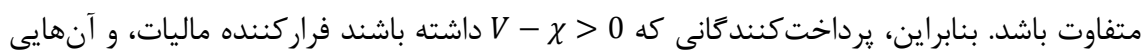

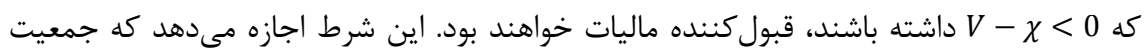

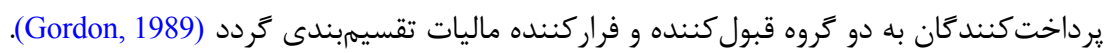
فرض جايكزين ديكر، افزايش و كاهش مطلوبيتى است كه از تعقيب هنجارهاى اجتماعى توسط 
قبول كننده و فراركننده ماليات ايجاد مى گردد. فرض بر اين است كه فايدهاى كه از افزايش مطلوبيت

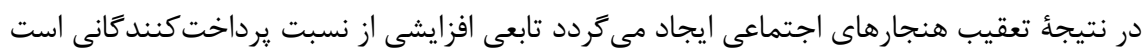

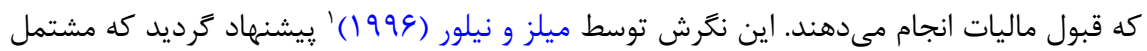

فرض شده است كه سطح مطلوبيت يرداخت كنندهاى كه با درآمد Y و نرخ ماليات $\tau$ مواجه

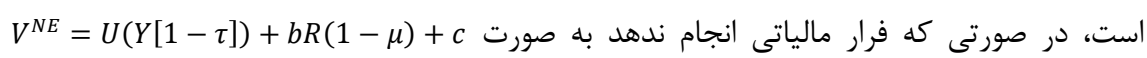

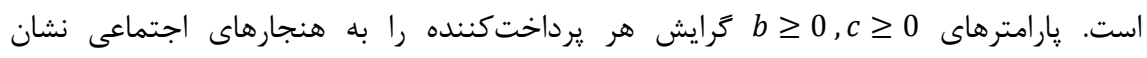
مى دهد كه انتظار بر اين است كه ميان يرداخت كنندكان مختلف متفاوت باشد و ر بنسبت جمعيت

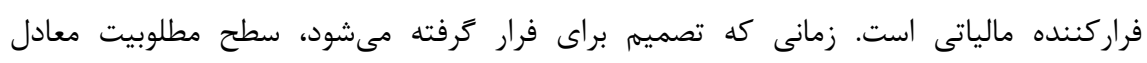
است كه بيان كننده آن است $V^{E}=\max \{P U(Y[1-\tau]-f \tau[Y-X])+[1-P] U(Y-\tau X)\}$ كه مطلوبيت ناشى از تعقيب هنجارهاى اجتماعى زمانى كه فرار انتخاب مى گردد كاهش مىيابد.

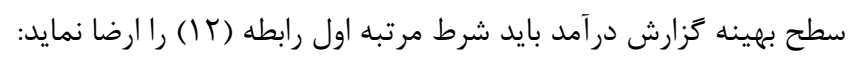
$P f U^{\prime}\left(Y[1-\tau]-f \tau[Y-X]-[1-P] U^{\prime}(Y-\tau X)=0\right.$ آنجه از شرط مرتبه اول استنباط مى گردد آن است كه اگر فرار انتخاب كردد، سطح عدم قبول

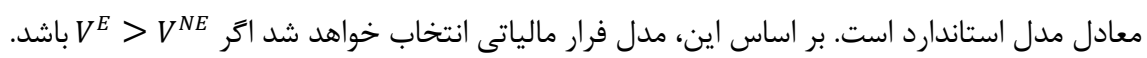

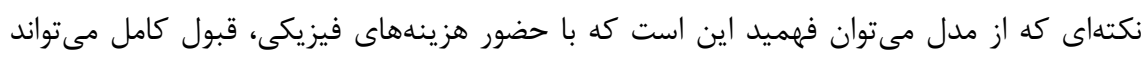

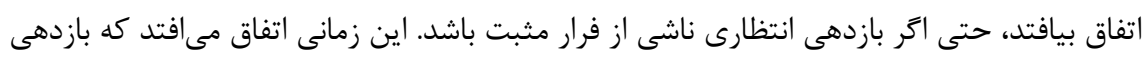

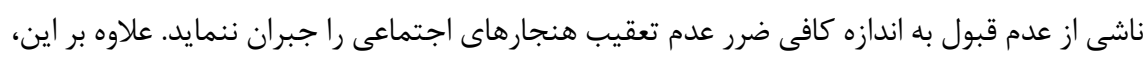
انتخاب فرار يا عدم فرار مالياتى بستكى به نسبت جمعيتى (ب) دارد كه فرار مالياتى انجام مي دهند.

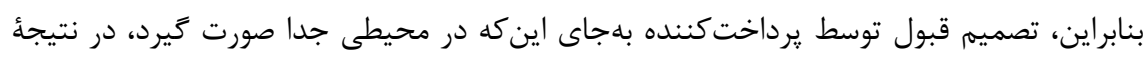

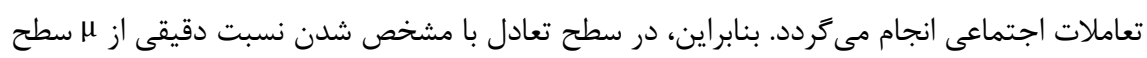
بهينه فرار مالياتى مشخص خواهد شد (Myles \& Naylor, 1996).

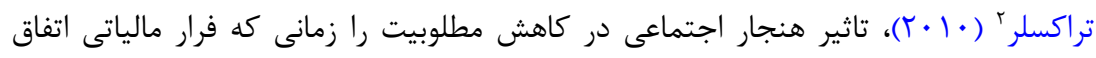

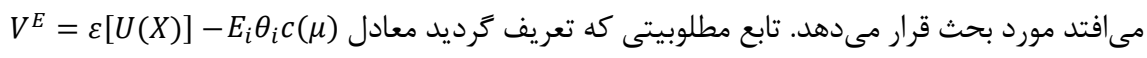

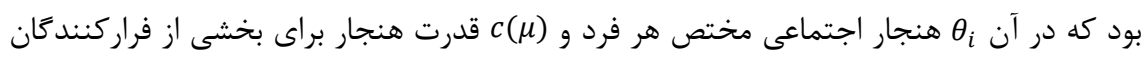




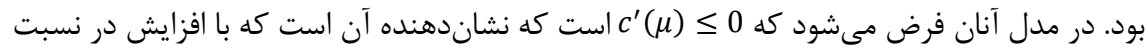

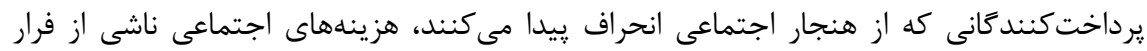
كاهش مى يابد (Traxler, 2010).

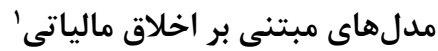

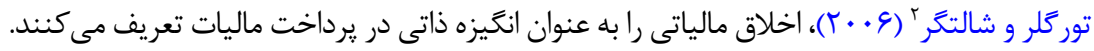

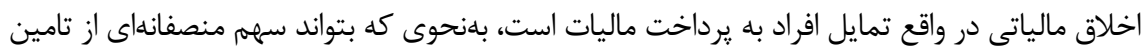

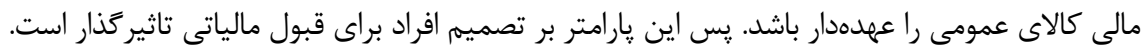

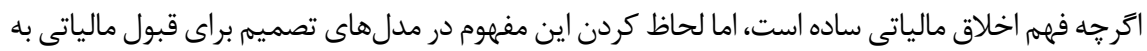

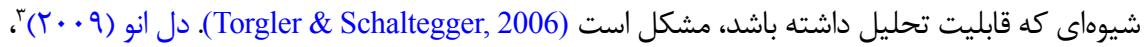

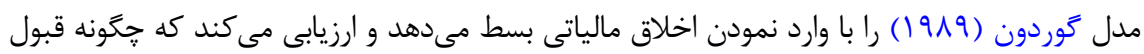

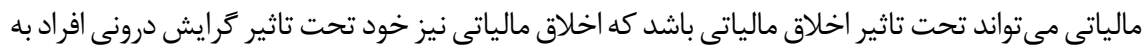

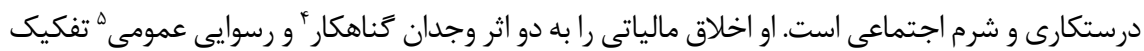

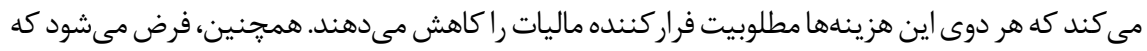

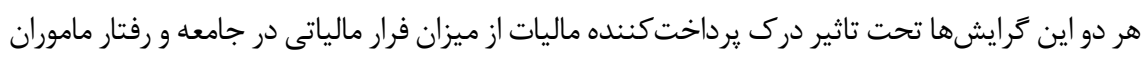

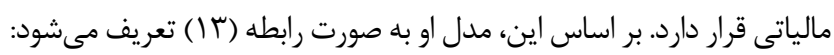
$V=p U\left(Y^{c}\right)+[1-p] U\left(Y^{n}\right)-v E-\emptyset \rho E$

كه در آن هزينههاى روانى vEv و

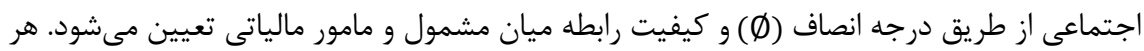

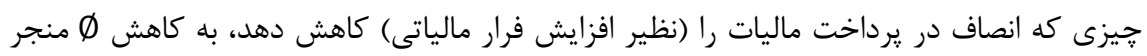
مىشود و هزينه شرم اجتماعى ناشى از فرار را كاهش مى دهد. بلمطور مشابه، كيفيت رابطه (م) (ر) نيز

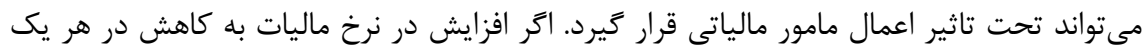

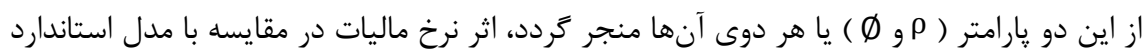

1. Tax Moral Models

2. Torgler \& Schaltegger

3. Dell'Anno

4 .Guilty Conscience

5. Public Disgrace 
مell'Anno, 2009)(Dell).

با معرفى هزينههاى فيزيكى، هنجارهاى اجتماعى و اخلاق مالياتى، مدلهاى اصلاحشده مبتنى

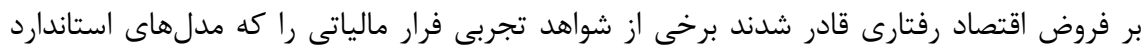
مطلوبيت انتظارى قادر به توضيح آن نبودند، بيان نمايند. بهطور خلاصه، مىتوان بيان نمود كه

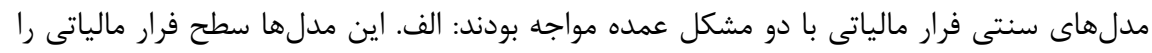

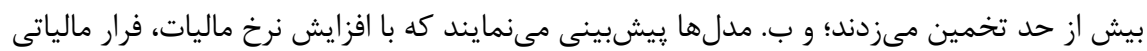
كاهش مى يابد كه در تضاد با شواهد تجربى است. اين نقايص به توسعه معنادار و بازبينى دوباره در ادبيات قبول مالياتى و استفاده از ايدههاى اقتصاد

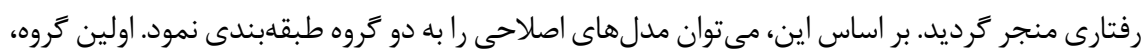
مدلهايى هستند كه مدل استاندارد را با استفاده از نظريه مطلوبيت غيرانتظارى اصلاح مى منمايند. اين مدلها دامنه وسيعترى را براى ترجيحات در نظر مى ميرند و محدوديتهايى را كه از طريق مطلوبيت

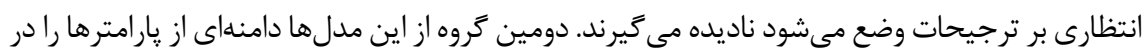

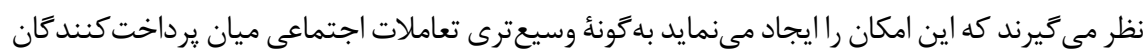
را منعكس نمايد. در نتيجه، اين مدلها ييشبينىهاى دقيقترى نسبت به مدل هاى استاندارد فراهم

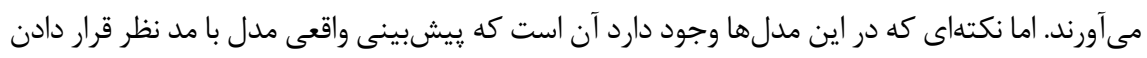

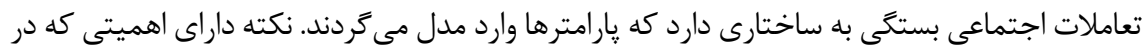

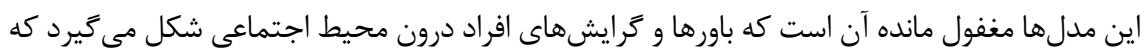

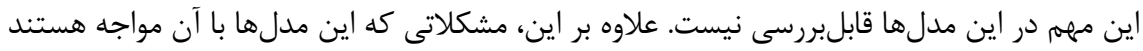

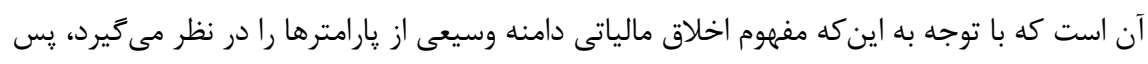

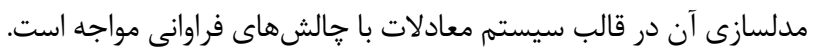


جدول ا: بررسى مقايسهاى مدلهاى ارزيابى فرار مالياتى

\begin{tabular}{|c|c|c|c|c|c|}
\hline ايرادها & منبع & شرح & متغيرهاى موثر & فروض & نظريه \\
\hline 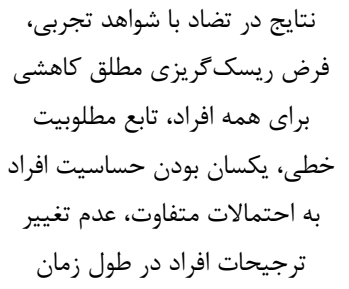 & $\begin{array}{l}\text { (Allingham } \\
\text { \& Sandmo, } \\
\text { 1972) }\end{array}$ & استفاده از ادبيات اقتصاد جرم و & در آمد، جريمه، نرخ ماليات، & 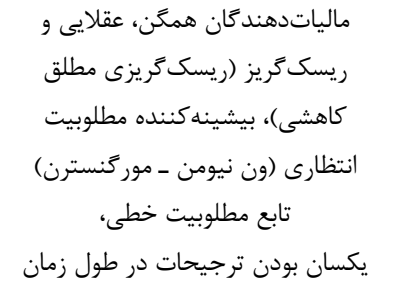 & 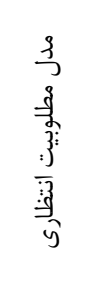 \\
\hline تناقض نتايج با شواهد تجربى & $\begin{array}{l}\text { (Quig- } \\
\text { gin, 1981; } \\
\text { Johanson \& } \\
\text { Schekade, } \\
\text { 1989) }\end{array}$ & 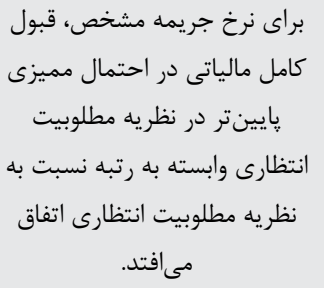 & 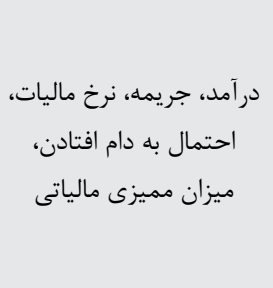 & 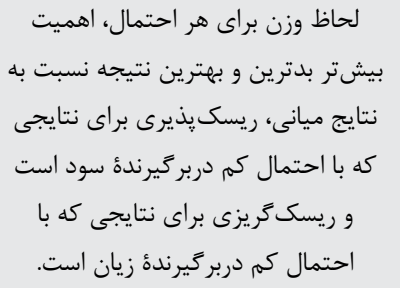 & 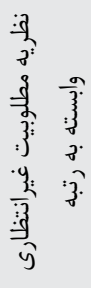 \\
\hline 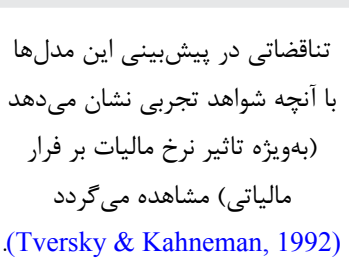 & $\begin{array}{l}\text { Tversky, 1979; } \\
\text { Hashimzade } \\
\text { et al., 2013; } \\
\text { Dehghan et } \\
\text { al., 2018) }\end{array}$ & 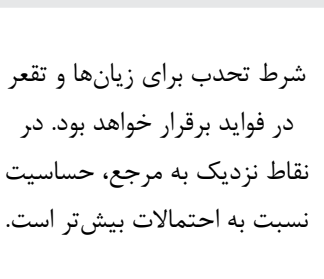 & درآمد، جريمه، نرخ ماليات، & 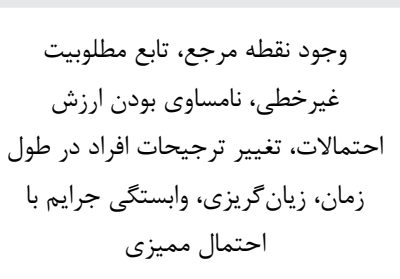 & 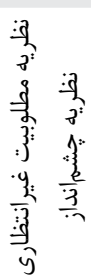 \\
\hline
\end{tabular}




\begin{tabular}{|c|c|c|c|c|c|}
\hline \multicolumn{6}{|c|}{ ادامه جدول ا: بررسى مقايسهاى مدلهاى ارزيابى فرار مالياتى } \\
\hline 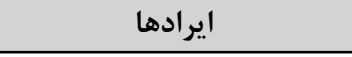 & 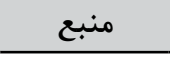 & 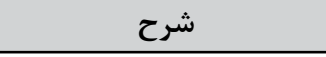 & متغير هاى موثر & 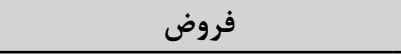 & نظريه \\
\hline 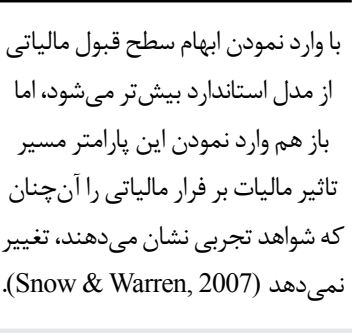 & $\begin{array}{c}\text { (Snow \& } \\
\text { Warren, 2007) }\end{array}$ & 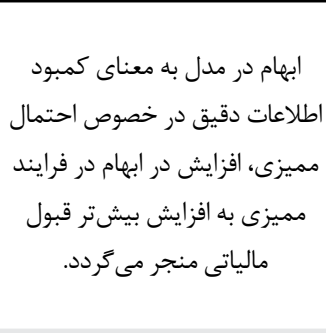 & درآمد، جريمه، نرخ ماليات، & 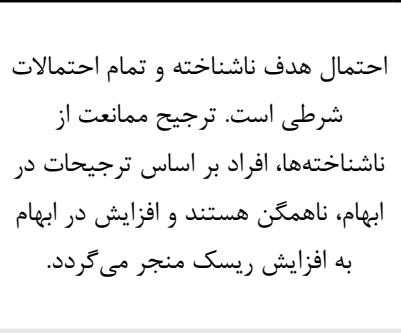 & 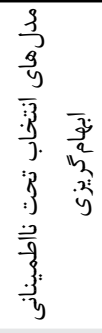 \\
\hline نبود انطباق با شواهد در رابطه ميان & $\begin{array}{l}\text { (Gordon, } \\
\text { 1989) }\end{array}$ & 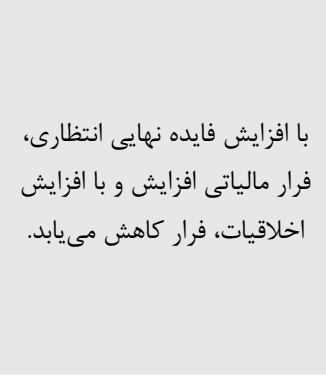 & 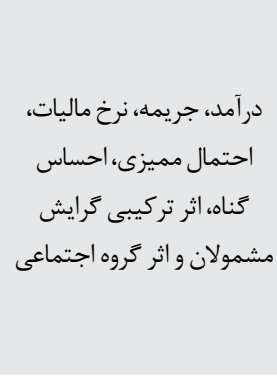 & فرار مالياتى شامل هزينههاى روانى از & 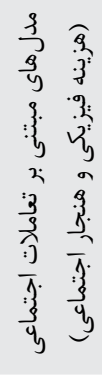 \\
\hline 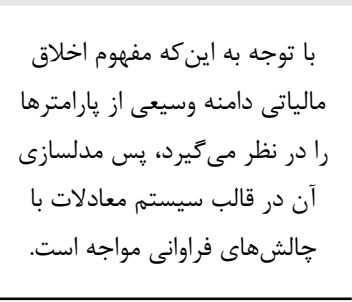 & $\begin{array}{l}\text { (Torgler \& } \\
\text { Schaltegger, } \\
\text { 2006; ; Gor- } \\
\text { don, 1989; } \\
\text { Frey \& Feld, } \\
\text { 2002) }\end{array}$ & 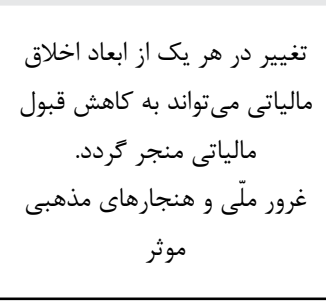 & 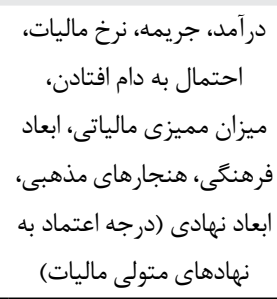 & 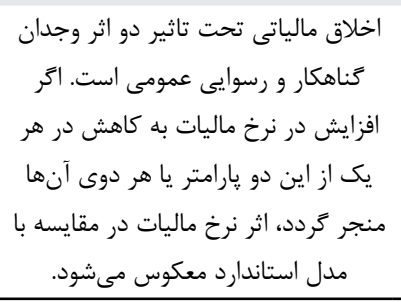 & 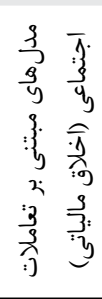 \\
\hline
\end{tabular}




\section{روش رشناسى يخوهش}

\section{روش تحليل سلسلهمراتبى}

مطابق محمد باقرى و جهانشاد (·r ·r)، در خصوص اولويتبندى معيارهاى فرار مالياتى بر اساس تكنيك AHP يا فرايند تحليل سلسلهمراتبى، در اين مطالعه نيز تلاش گرديد بر اساس منطق AHP مدلهاى مختلف فرار مالياتى بر اساس معيارهاى مرتبط با هر مدل بر اساس نمونهاى متشكل

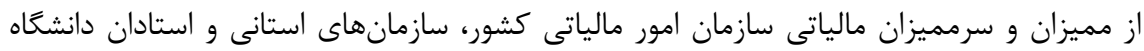
متخصص در حوزه ماليات اولويتبندى كردد. اولين كام براى شناسايى يارامترهاى كليدى كه در انتخاب فرد در فرار مالياتى تاثير مى گذارد مرور ادبيات فرار مالياتى و شناسايى متغيرهاى اثرگذار

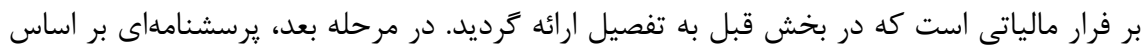

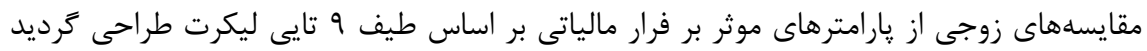
(جدول r). در گام نهايى تحليل دادهها و محاسبه اهميت هر يك از عوامل با استفاده از تحليل سلسلهمراتبى انجام گرفت. روش تحليل سلسلهمراتبى (AHP) به افراد اجازه مىدهد اهميت نسبى

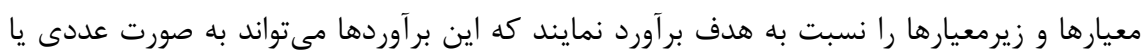
لغوى باشد.

\section{جدول r: نحوه كامل كردن يرسشنامه}

\begin{tabular}{|c|c|c|c|c|c|c|c|c|c|c|c|c|c|c|c|c|c|c|}
\hline معيار & & & & & & & & & مسر & ت & & & & & & & & معيار \\
\hline A & 9 & $\Lambda$ & $V$ & 4 & $\Delta$ & $f$ & r & $r$ & 1 & $r$ & r & $f$ & $\Delta$ & 4 & V & $\Lambda$ & $q$ & B \\
\hline
\end{tabular}

در خصوص انتخاب تعداد افراد نمونه در ادبيات مربوط به روشهاى سنجش نظر خبركان،

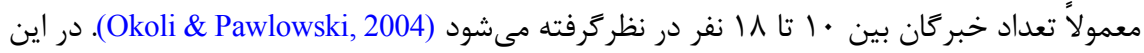

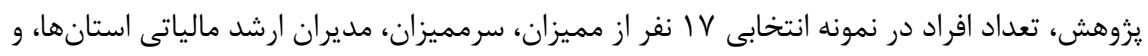
استادان دانشعاه در حوزه اقتصاد بخش عمومى بودهاند كه از طريق ارسال يرسشنامه برخط (آنلاين) و مصاحبه حضورى يس از تشريح و تبيين نحوه ياسخكويى و وزندهى به معيارها به يرسشها پاسخ

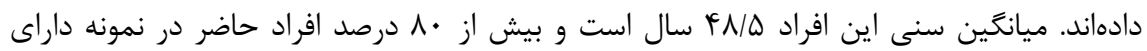
تحصيلات كارشناسى ارشد و بالاتر هستند. در اين يزوهش، به منظور تجزيهوتحليل نتايج AHP از 
نرمافزار Expert Choice11 استفاده شده و نتايج حاصل از IV يرسشنامه مبتنى بر نظرسنجى از

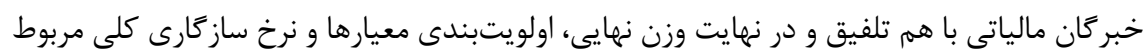
به معيارها بهدست آمده است.

\section{ساخت سلسلهمراتبى}

مسئله در اين مرحله تعريف مىشود و هدف از تصميمگيرى به صورت سلسلهمراتبى از عوامل و عناصر تشكيلدهنده تصميم ترسيم مىشود. فرايند تحليل سلسلهمراتبى، نيازمند شكستن مسئله

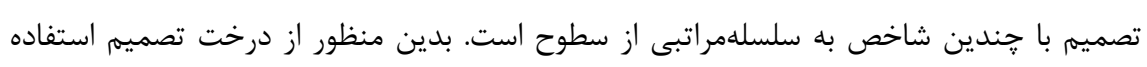
مىشود كه داراى سه سطح است: سطح اول شامل هدف كلى تصميمثيرى است. در سطح دوم

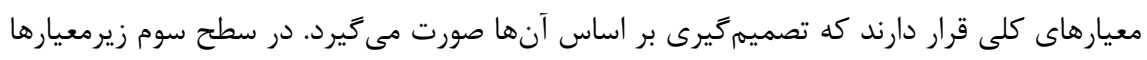

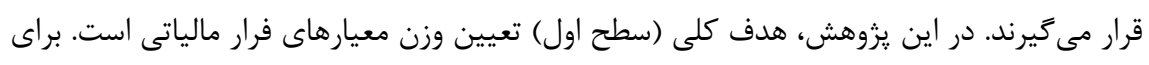

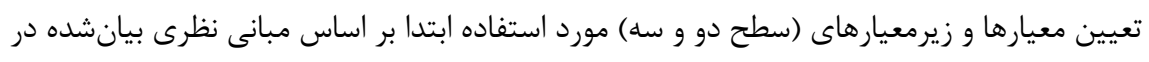
خصوص مدلهاى فرار مالياتى، فروض و متغيرهاى موثر هر يك از مدلها استخراج شده است (جدول

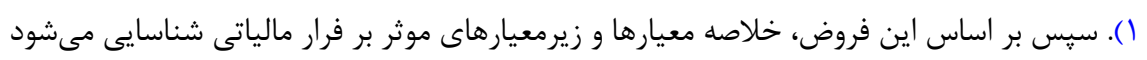
كه در شكل (D) ارائه مى كردد. 


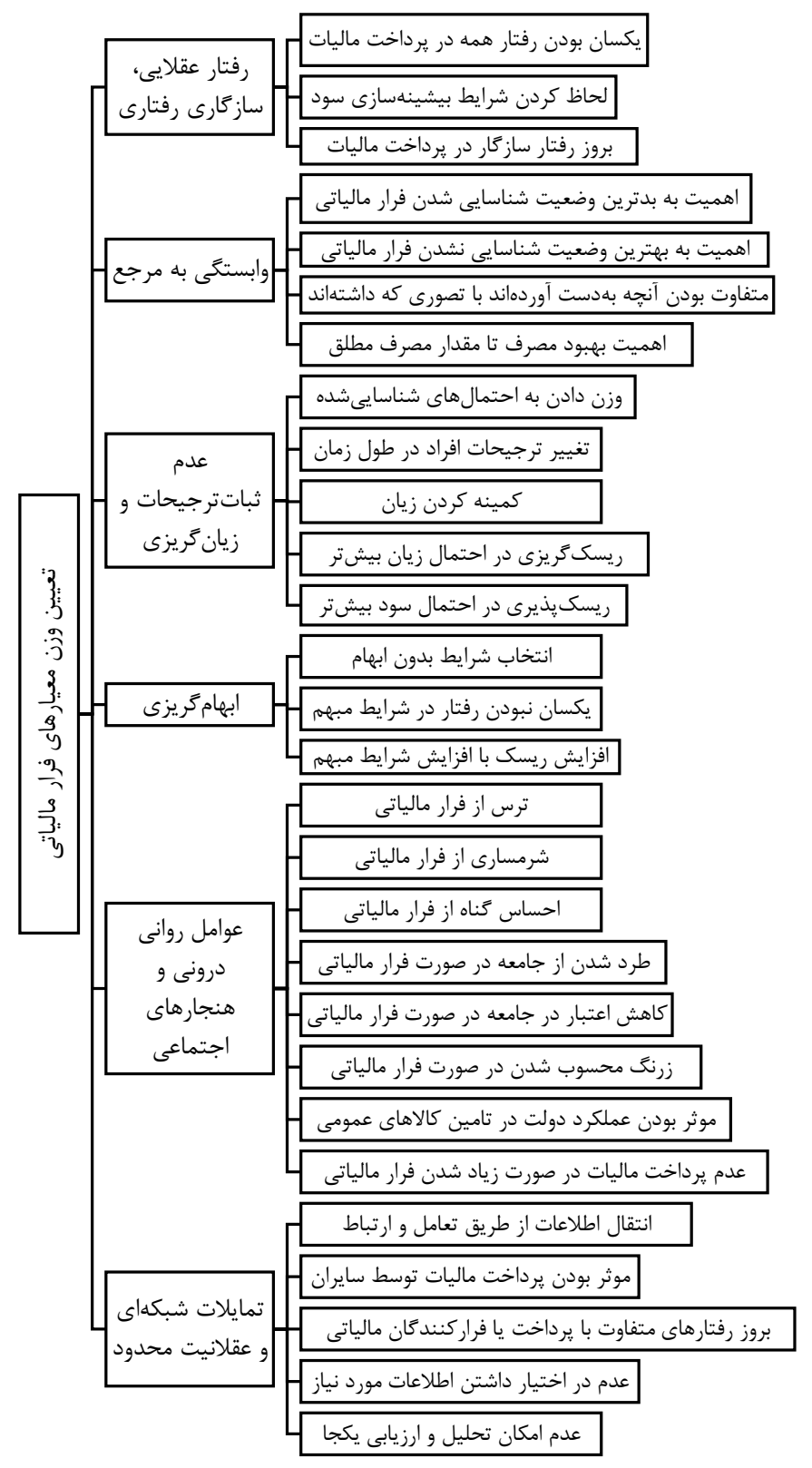




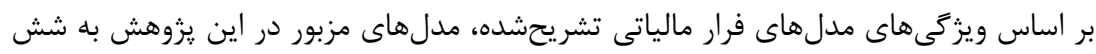

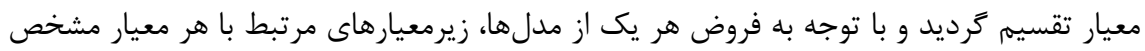

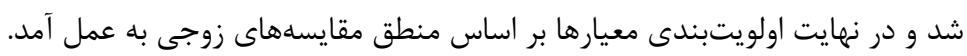

خبركان در اين مرحله مقايسههايى را ميان معيارها و زيرمعيارهاى تصميمَيرى انجام ميدهند

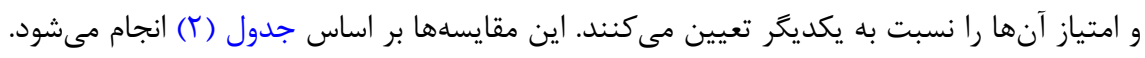

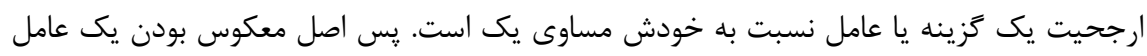

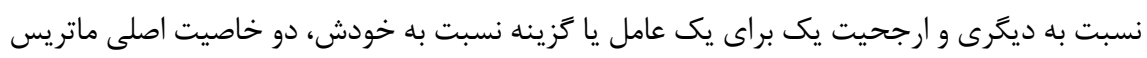

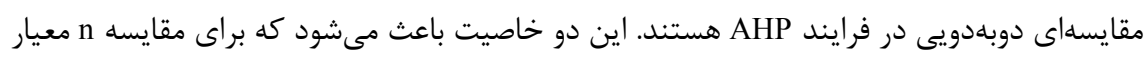

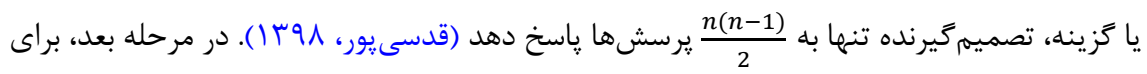

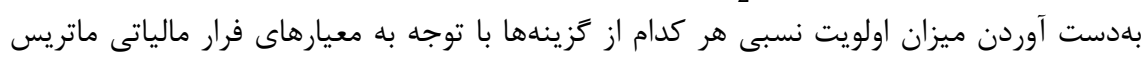

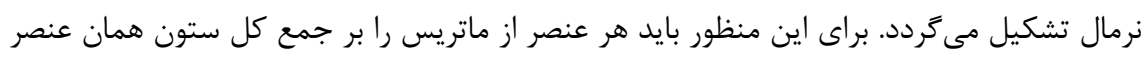

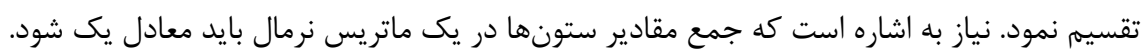

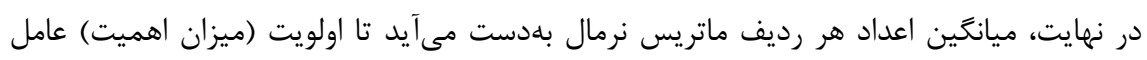
مربوط در سطر مذكور بهدست آورده شود.

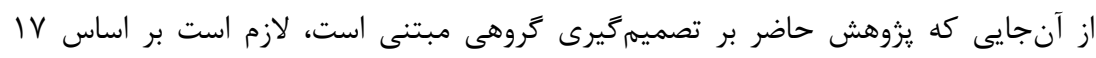

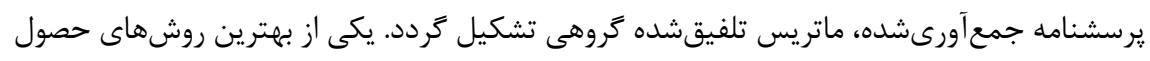

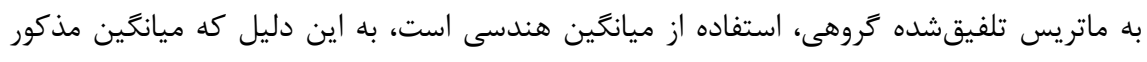

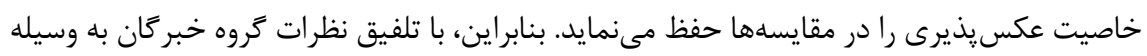

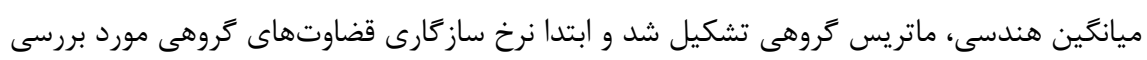

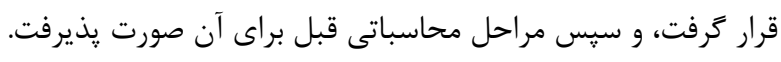

تجزيهوتحليل اطلاعات

بر رسى سازعارى در قضاوتها يكى از مزاياى فرايند تحليل سلسلهمراتبى كنترل سازكارى در قضاوتهاى انجامشده براى تعيين 
ضريب اهميت معيارها و ززينهاست. به عبارت ديخر، اطلاع از سازگارى قضاوتها به اين دليل داراى

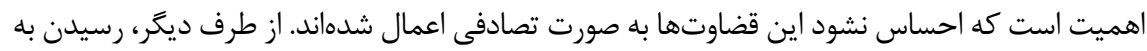
ساز كارى كامل مشكل است. وقتى اهميت معيارها نسبت به يكديگر برآورد مىشود، احتمال ناساز گارى

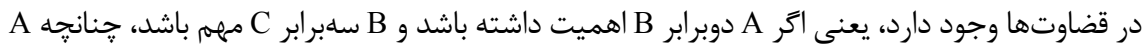

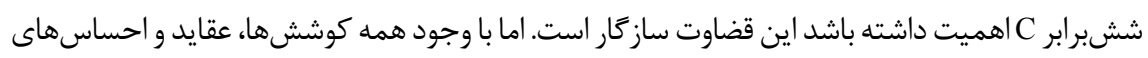

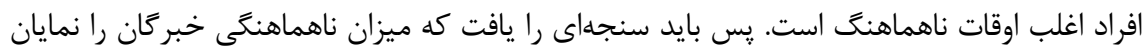

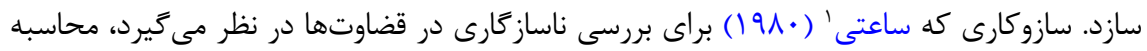

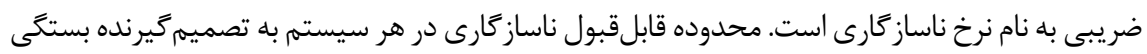

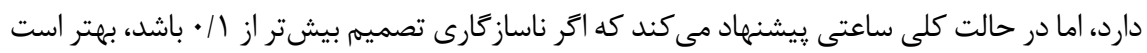

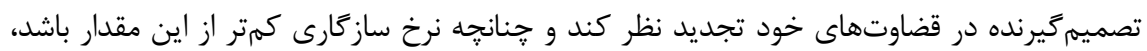

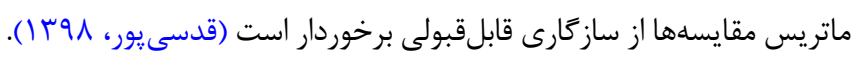

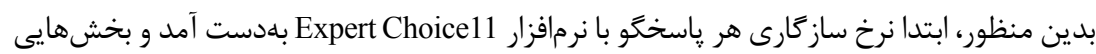

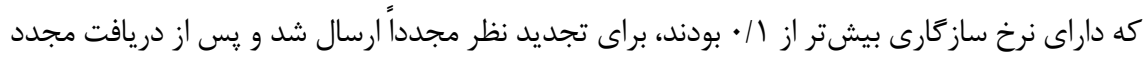

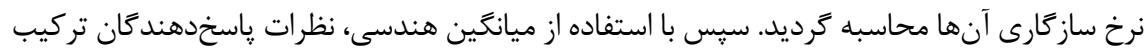

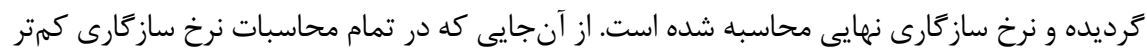

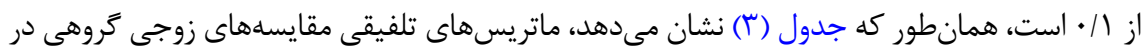

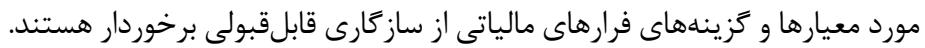

\begin{tabular}{|c|c|}
\hline نرخ سازگَارى & 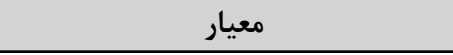 \\
\hline$\cdot 1 \cdot \cdot 1$ & رفتار عقلايى و سازكارى رفتارى \\
\hline$\cdot 1 \cdot \cdot \Delta$ & وابستكى به مرجع \\
\hline$\cdot / \cdot r$ & عدم ثبات ترجيحات و زيان گريزى \\
\hline$\cdot 1 \cdot \Delta$ & ابهام \\
\hline$\cdot / \cdot 1$ & عوامل روانى درونى و هنجارهاى اجتماعى \\
\hline$\cdot / \cdot r$ & تمايلات شبكهاى و عقلانيت محدود \\
\hline
\end{tabular}




\section{اولويتبندى معيار هاى فرار مالياتى}

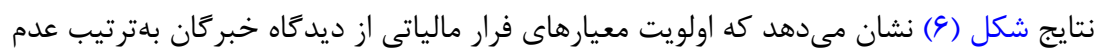

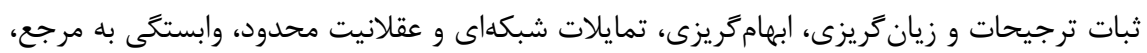

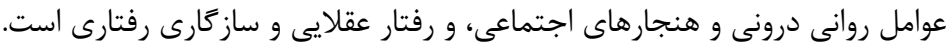

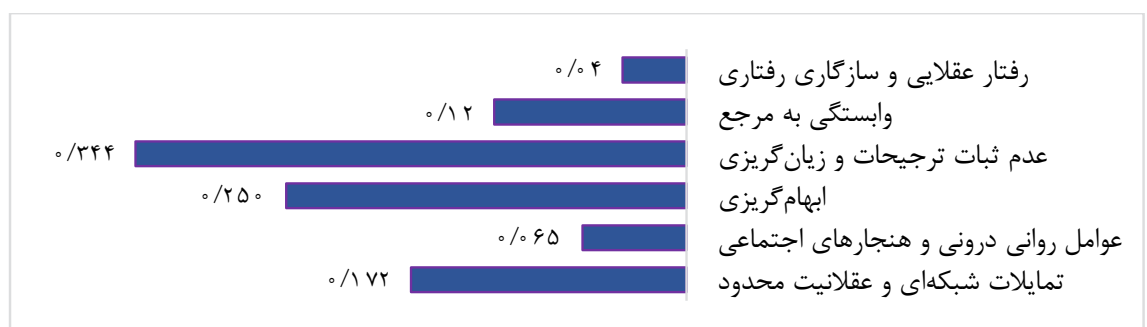

شكل 9: اولويتبندى معيارهاى فرار مالياتى

همانطور كه در شكل (9) نشان داده ميشود، عدم ثبات ترجيحات و زيانكريزى كه خود

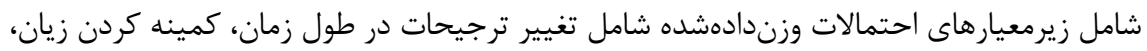

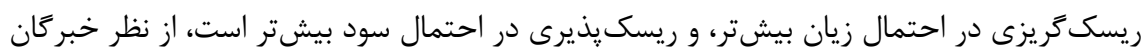

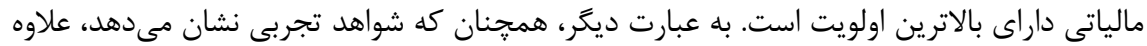
بر اينكه ترجيحات افراد در طول زمان دستخوش تغيير مى گردد، افراد نسبت به زئ زيان حساسيت

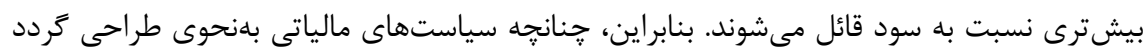

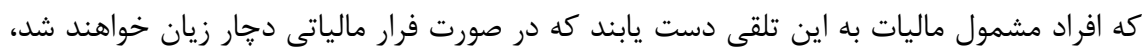

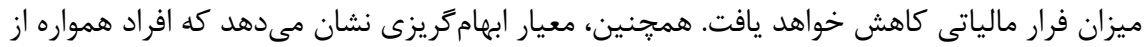

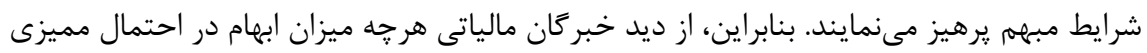
بيشتر باشد، ميزان فرار مالياتى كاهش مى بيابد،

\section{بحث و نتيجه}

با توجه به اهميت درآمدهاى مالياتى در تامين مالى منابع در آمدى دولت و تاثيرى كه فرار مالياتى بر عدم تحقق درآمدها و تخصيص نامناسب مخارج عمومى دولت ايفا مىنمايد، شناسايى عوامل 
موثر بر فرار مالياتى و ارائه راهكارهاى اثربخش براى كاهش اين يديده كه دولتها را در رسيدن به

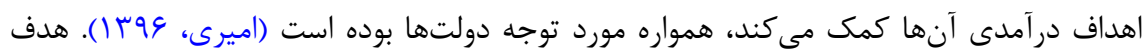
يزوهش حاضر، شناسايى اصلىترين يارامترهاى موثر بر فرار مالياتى در اقتصاد ايران به منظور اتخاذ سياستخذارى بهينه مالياتى در راستاى كاهش فرار مالياتى و افزايش درآمدهاى مالياتى دولت است.

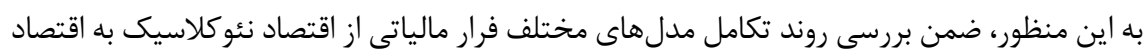

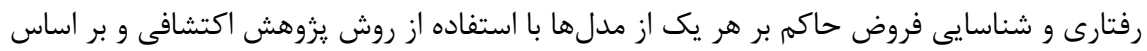

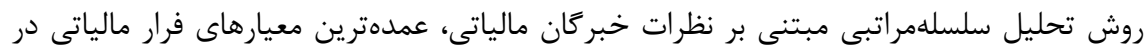
اقتصاد ايران شناسايى شدند. نتايج نشان مىدهد كه عدم ثبات ترجيحات و زيانكريزى و ابهامگريزى از ديدگاه خبركان مالياتى، عوامل اصلى تاثير گذار بر فرار مالياتى هستند. بدبينى ناشى از باور غيرمنطقى از وقوع يك حادثه نامطلوب (زيان ناشى از شناخته شدن به عنوان فراركننده مالياتى) به اين تصميم منجر مى شود

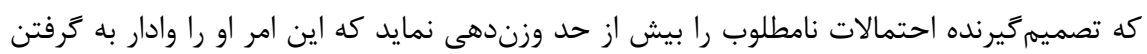

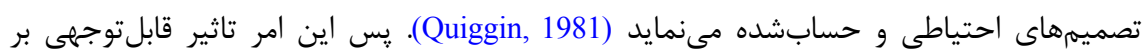
كاهش فرار مالياتى به منظور اجتناب از يرداخت جرايم مالياتى داشته كه از ديدگاه خبركان مالياتى نيز داراى اهميت شناخته شده است.

از آنجا كه يرسشهاى مهرم سياستى درباره اثر شفافيت بيشتر يا كمتر بر فرايند مميزى مطرح است و با توجه به اينكه از يك طرف ترجيحات افراد در طول زمان و با توجه به عوامل اقتصادى -

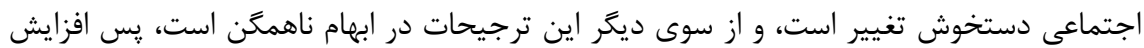

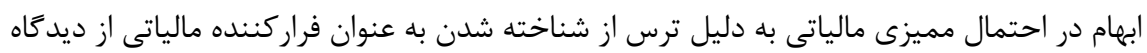

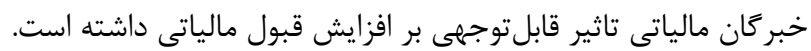
بررسى مطالعات انجاميافته در خصوص فرار مالياتى در اقتصاد ايران نشان مىدهد كه رويكرد بيشتر اين يزوهشها مبتنى بر مدلهاى استاندارد فرار مالياتى (رفتار عقلايى و سازكارى رفتارى)

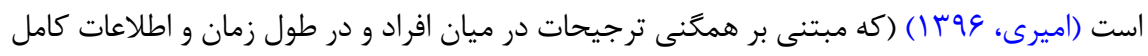

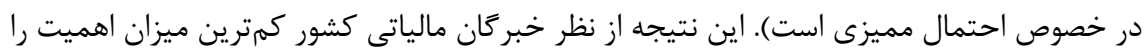

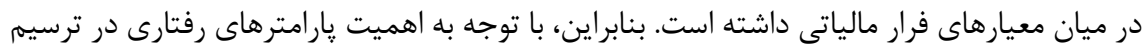

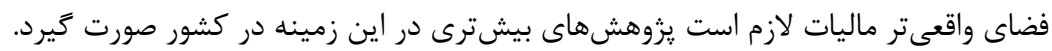

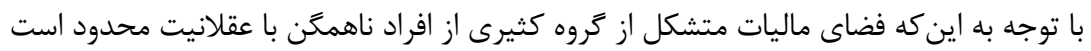


كه در تعامل با يكديكر قرار دارند، پس به منظور شناخت دقيق محيط ماليات در هر كشور نياز است

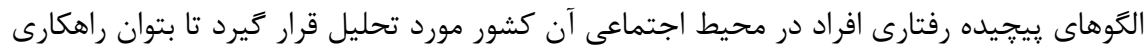

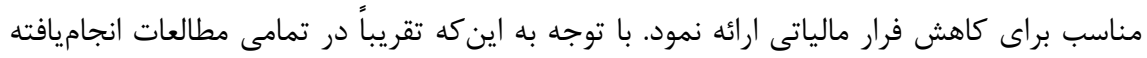

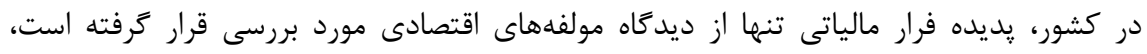

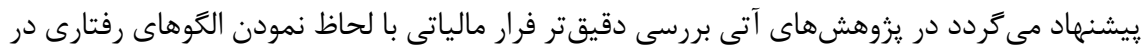

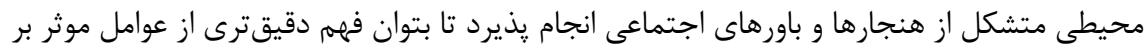

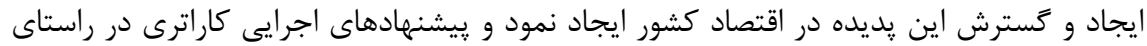
سياستخذارى اثربخش مالياتى به مسئولان مالياتى كشور ارائه نمود.

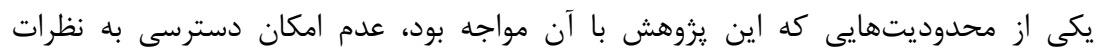
كارشناسان خبره مالياتى در كل استانهاى كشور بود. اما نتايج نظرسنجى از كارشناسان خبرهاى كه در اين نظرسنجى شركت نمودهاند نشان داده كه عوامل رفتارى و اجتماعى نقش انكارنايذيرى در فرار مالياتى در كشور داشتهاند.

در اين يزوهش همكاران علمى، داوران ناشناس، و ويراستار علمى نشريه برنامهريزى و بودجه (مازيار קابك) نكات ارزشمندى مطرح نمودند كه باعث بهبود قابلتوجه محتواى يزوهش شد. از اينرو، نويسندكان بر خود لازم مى دانند كه از آنان به دليل همكارى صميمانهشان سياسگزارى نمايند.

\section{منابع}

Allingham, M. G., \& Sandmo, A. (1972). Income Tax Evasion: A Theoretical Analysis. Taxation: Critical Perspectives on the World Economy, 3(1), 323-338.

Andrei, A. L., Comer, K., \& Koehler, M. (2014). An Agent-Based Model of Network Effects on Tax Compliance and Evasion. Journal of Economic Psychology, 40(1), 119133. https://doi.org/10.1016/j.joep.2013.01.002

Andreoni, J., Erard, B., \& Feinstein, J. (1998). Tax Compliance. Journal of Economic Literature, 36(2), 818-860.

Cartwright, E. (2018). Advanced Introduction to Behavioral Economics by John F. Tomer. South-Eastern Europe Journal of Economics, 16(1), 93-99. 
Cowell, F. (2003). Sticks and Carrots. Distributional Analysis Research Programme, Discussion Paper No. 68.

Dehghan, S., Mousavi Jahromi, Y., \& Abdoli, G. (2018). Prospect Theory; New Approach in Explaining Tax Evasion Phenomenon. Journal of Economic Research (TahghighatE-Eghtesadi), 53(1), 1-23. https://dx.doi.org/10.22059/jte.2018.64841

Dell'Anno, R. (2009). Tax Evasion, Tax Morale and Policy Maker's Effectiveness. The Journal of Socio-Economics, 38(6), 988-997. https://doi.org/10.1016/j.socec.2009.06.005

Fotros, M. H., \& Dalaei Milan, A. (2016). Examination of Underground Economy and Tax Evasion within the Framework of Dynamic Stochastic General Equilibrium Models (DSGE). Quarterly Journal of Economic Growth and Development Research, 7(25), 6584. http://egdr.journals.pnu.ac.ir/article_2588.html

Frey, B. S., \& Feld, L. P. (2002). Deterrence and Morale in Taxation: An Empirical Analysis. Cesifo Working Paper No. 760.

Friedland, N. (1982). A Note on Tax Evasion as a Function of the Quality of Information about the Magnitude and Credibility of Threatened Fines: Some Preliminary Research. Journal of Applied Social Psychology, 12(1), 54-59. https://doi.org/10.1111/j.1559-1816.1982.tb00848.x

Gordon, J. P. (1989). Individual Morality and Reputation Costs as Deterrents to Tax Evasion. European Economic Review, 33(4), 797-805. https://oi.org/10.1016/0014-2921(89)90026-3

Hadian, E., \& Tahvili, A. (2013). Tax Evasion and Its Determinants in the Iranian Economy (1971-2007). The Journal of Planning and Budgeting, 18(2), 39-58. http://jpbud.ir/article-1-982-fa.html

Hashimzade, N., Myles, G. D., \& Tran-Nam, B. (2013). Applications of Behavioural Economics to Tax Evasion. Journal of Economic Surveys, 27(5), 941-977. https://doi.org/10.1111/j.1467-6419.2012.00733.x

Hokamp, S. (2014). Dynamics of Tax Evasion with Back Auditing, Social Norm Updating, and Public Goods Provision-An Agent-Based Simulation. Journal of Economic Psychology, 40(1), 187-199. https://doi.org/10.1016/j.joep.2013.01.006

Hokamp, S., Gulyás, L., Koehler, M., \& Wijesinghe, S. (2018). Agent-Based Modeling of Tax Evasion: Theoretical Aspects and Computational Simulations: John Wiley \& Sons.

Johnson, E. J., \& Schkade, D. A. (1989). Bias in Utility Assessments: Further Evidence and Explanations. Management Science, 35(4), 406-424. https://doi.org/10.1287/mnsc.35.4.406

Kahneman, D., \& Tversky, A. (1979). Prospect Theory: An Analysis of Decision Under Risk. Econometrica, 47(2), 363-391.

Korobow, A., Johnson, C., \& Axtell, R. (2007). An Agent-Based Model of Tax Compliance with Social Networks. National Tax Journal, 60(3), 589-610.

Medina, L., \& Schneider, M. F. (2018). Shadow Economies Around the World: What Did We Learn over the Last 20 Years? International Monetary Fund.

Mohammad Bagheri, M., \& Jahanshad, A. (2020). Identifying and Prioritizing Factors ResponsibleforTaxEvasionandSelectingtheBestSoloutiontoReduseIt.QuarterlyJournalofthe Macro and Strate-gic Policies, 7(1), 118-137. https://dx.doi.org/10.30507/jmsp.2020.102396

Mosleh Shirazi, A., Namazi, M., Mohammadi, A., \& Rajabi, A. (2013). Prospect Theory and Modeling Industrial Manager Decision Making Pattern. Journal of Industrial Management Perspective, 3(2), 9-33. http://jimp.sbu.ac.ir/article_87311.html

Motallebi, M., Alizadeh, M., \& Faraji Dizaji, S. (2020). Estimating Shadow Economy and 
Tax Evasion using Governmental Financial Discipline Variables. Quarterly Journal of Quantitative Economics, 16(4), 69-100. https://dx.doi.org/10.22055/jqe.2019.26886.1926

Myles, G. D., \& Naylor, R. A. (1996). A Model of Tax Evasion with Group Conformity and Social Customs. European Journal of Political Economy, 12(1), 49-66. https://doi.org/10.1016/0176-2680(95)00037-2

Okoli, C., \& Pawlowski, S. D. (2004). The Delphi Method as a Research Tool: An Example, Design Considerations and Applications. Information \& Management, 42(1), 15-29. https://doi.org/10.1016/j.im.2003.11.002

Pratt, J. W. (1978). Risk Aversion in the Small and in the Large. In Uncertainty in Economics (pp. 59-79): Elsevier. https://doi.org/10.1016/B978-0-12-214850-7.50010-3

Quiggin, J. (1981). Risk Perception and Risk Aversion among Australian Farmers. Australian Journal of Agricultural Economics, 25(2), 160-169. https://doi.org/10.1111/j.1467-8489.1981.tb00393.x

Rezagholizadeh, M., Aghaei, M., \& Alami, A. (2019). Estimating Tax Evasion in Iran and Investigating Its Causes and Effects: A Multiple Indicators-Multiple Causes (MIMIC) Approach. Majlis and Rahbord, 26(97), 191-226. https://nashr.majles.ir/article_301.html

Saaty, T. L. (1980). The Analytic Hierarchy Process: McGrew Hill.

Sadeghi, H., \& Shakibaei, A. (2001). Tax Evasion and the Size of Iran's Underground Economy. The Journal of Economic Studies and Policies, 1(27), 55-76. http://economic.mofidu.ac.ir/article_47839.html

Slemrod, J., \& Yitzhaki, S. (2002). Tax Avoidance, Evasion, and Administration. In Handbook of Public Economics (Vol. 3, pp. 1423-1470): Elsevier. https://doi.org/10.1016/S1573-4420(02)80026-X

Snow, A., \& Warren Jr, R. S. (2007). Audit Uncertainty, Bayesian Updating, and Tax Evasion. Public Finance Review, 35(5), 555-571. https://doi.org/10.1177/1091142107299609

Torgler, B., \& Schaltegger, C. A. (2006). Tax Morale: A Survey with a Special Focus on Switzerland. Swiss Journal of Economics and Statistics (SJES), 142(III), 395-425.

Traxler, C. (2010). Social Norms and Conditional Cooperative Taxpayers. European Journal of Political Economy, 26(1), 89-103. https://doi.org/10.1016/j.ejpoleco.2009.11.001

Tversky, A., \& Kahneman, D. (1992). Advances in Prospect Theory: Cumulative Representation of Uncertainty. Journal of Risk and Uncertainty, 5(4), 297-323. https://doi.org/10.1007/BF00122574

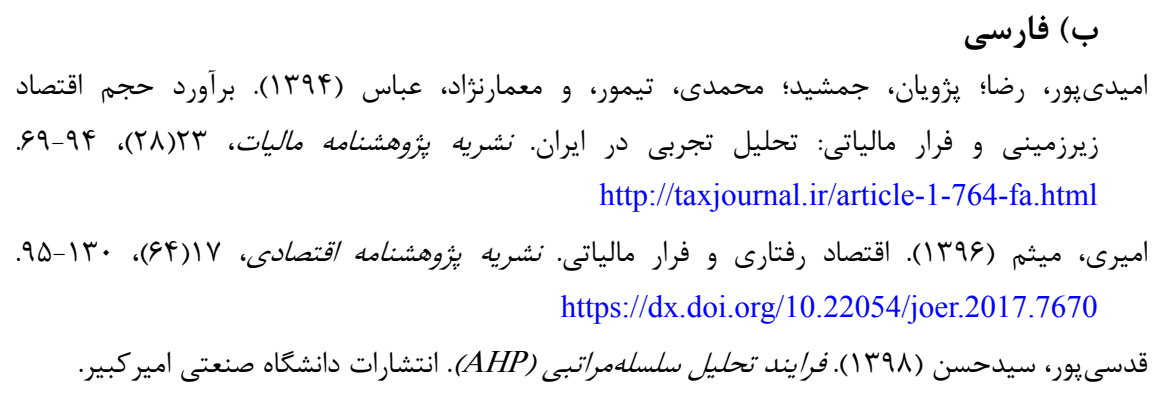

